\title{
Socio-Economic Constraints Affecting Sustainable Rural Livelihood
}

Abdul Sajid ${ }^{\star 1}$, Ayatullah², Amir Nawaz Khan ${ }^{3}$, Shahid Iqbal ${ }^{4}$, Sudhair Abbas ${ }^{5,6}$, Intikhab Alam Natasha Kashif ${ }^{7}$, Saeed Muhammad ${ }^{8}$ and Mian Muhammad Salman ${ }^{1}$

${ }^{1}$ College of Veterinary Sciences and Animal Husbandry, Abdul Wali Khan University, Garden Campus, Mardan, Pakistan

${ }^{2}$ Department of Agricultural Extension Education and Communication, Faculty of Rural Social Sciences, Agricultural University Peshawar, Pakistan

${ }^{3}$ Department of Life and Environmental Sciences, University of Peshawar, Pakistan

${ }^{4}$ Department of Disaster Preparedness and Management, University of Peshawar, Pakistan

${ }^{5}$ Sarhad University of Science and Information Technology, Peshawar, Pakistan

${ }^{6}$ Department of Rural Sociology, Faculty of Rural Social Sciences, Agricultural University Peshawar, Pakistan

${ }^{7}$ Department of Microbiology, Abasyn University, Peshawar, Pakistan

${ }^{8}$ National Reference Laboratory of Veterinary Drug Residues (HZAU), China

\begin{abstract}
The present study about "Constraints of rural livelihood with reference of services providers and rural female in Mansehra" was conducted with objectives to determine the constraints of rural livelihood and the role of services providers i.e. government and NGOs and the rural female in enhancing rural livelihood. A sample size 210 respondents out of 460 was selected through random sampling procedure. The study concluded that a highly significant association was found between rural livelihood and finance is the core problem for all categories of entrepreneurs in rural areas was found highly significant $(p=0.000)$, poor health issues block sustainability of rural livelihood $(p=0.000)$, prevalence of diseases in livestock and crops contribute income decline in rural areas $(p=0.003)$, marketing problem is a major obstacle in rural economy production $(p=0.003)$, land shortage affects rural economy $(p=0.005)$ and rural livelihoods affect adversely by any kind of shock $(p=0.007)$ while Illiteracy affects negatively sustainability of rural livelihood $(p=0.014)$, conflict leads decline in rural livelihoods $(p=0.021)$. In addition, highly significant relationship was found $(p=0.000)$ between rural livelihood and through NGOs efforts people adopted ability for livelihood choices. Moreover, skill development training on male side contributed good results in enhancing livelihood $(p=0.018)$, microfinance service of government/NGOs plays a pivotal role in the development of rural economy $(p=0.031)$,through rural livelihood programs, the NGO is promoting livelihood and food security activities $(p=0.025)$, protective interventions are considered vital to facilitating livelihood recovery $(p=0.016)$ and between livelihood promotion through irrigation development and introducing of productive yield is a good step by the government $(p=0.024)$ had significant relation with rural livelihood. Furthermore, significant relation was found between absence of basic livelihood assets for female makes unstable livelihood $(p=0.003)$, kitchen gardening, poultry and livestock rearing are major livelihood activities of rural female $(p=0.004)$, female make contribution to run livelihood system to contribute household expenses $(p=0.029)$ and rural livelihood. In light of the study it was suggested to policy makers to provide assistance in term of material and capacity building i.e. easy credit system, agriculture, livestock, health, illiteracy interventions and NGOs and rural female participation in sustaining rural livelihood to minimize the risk of rural livelihood vulnerability.
\end{abstract}

Keywords: Rural livelihood; Socioeconomic constraints; Rural women's contribution

\section{Introduction}

Rural livelihood is defined by Robert Chambers and Gordon Conway as livelihood comprises the capabilities, assets and activities required for a means of living, a livelihood is sustainable which can cope with and recover from stress and shocks, maintain or enhance its capabilities and assets, and provide sustainable livelihood opportunities for the next generation [1]. Livelihood is also defined as adequate stocks and flows of food and cash to meet basic needs. Sustainable refers to the maintenance or enhancement of resource productivity on a long term basis so that a family or communities cope with chronic situation. A household may be enables to gain sustainable livelihood in many ways i.e. through ownership of land, livestock or trees, right to grazing, fishing, hunting or gathering through stable employment with adequate remuneration or through varied range of activities. Perret et al. define that the term "livelihood" is used rather than "job" or even "source of income" [2]. First, most rural people work in agriculture as farmers or farm workers or get non-farm job opportunities only seasonally and often part time. Second, individuals and households create a living from various sources i.e. farming, local craftwork, small-scale industries, own labour and trading, this form the backbone of rural people's livelihood in the world. ZimVac mentioned that different socioeconomic factors lead to decline in rural livelihood. Khatun and Roy stated that rural livelihoods are affected by socioeconomic constrains and calamities [3].

The Zimbabve Vulnerability assessment Committee, ZimVac after a detail study of Rural Livelihood in different rural areas of Zimbabve presented a crystal clear report indicating the rural livelihoods and the vulnerability of rural households affecting the sustainability of livelihood resulting extreme poverty. The report showed the reality of rural livelihood vulnerability with clear cut mentioning the socioeconomic factors as poverty, poor roads, transport, infrastructure and communication, water shortage, poor access to education, inadequate health facilities, poor water and sanitation, unavailability of agriculture

*Corresponding author: Abdul Sajid, College of Veterinary Sciences and Animal Husbandry, Abdul Wali Khan University, Garden Campus, Mardan, Pakistan, Tel: +92-9379230640; E-mail: Sajidvet137@awkum.edu.pk

Received December 06, 2017; Accepted December 29, 2017; Published January 04, 2018

Citation: Sajid A, Ayatullah, Khan NA, Iqbal S, Abbas S, et al. (2018) SocioEconomic Constraints Affecting Sustainable Rural Livelihood. Arts Social Sci J 9: 324. doi: $10.4172 / 2151-6200.1000324$

Copyright: ( 2018 Sajid A, et al. This is an open-access article distributed under the terms of the Creative Commons Attribution License, which permits unrestricted use, distribution, and reproduction in any medium, provided the original author and source are credited. 
inputs, poor rainfall, poor market and prices, food insecurity, unemployment, lack of capital, livestock diseases, wild animals, lack of NGOs and government interventions, land shortage and power shortage. The report contains suggestions and recommendations to handle the vulnerable situation for ensuring sustainable rural livelihood. WFP et al. stated that because of a number of reasons the livelihood system could not get sustainability in both rural and urban areas of Darfur [4]. The major socio-economic challenges indicated in the study by FAO and WFP include limited water resources for crops and livestock, declining soil fertility, lack of extension services for farmers and livestock keepers, high level of crop pest infestation, use of poor quality seeds, unstable product prices, conflicts over land and water resources, prevalence of heavy livestock diseases, drought and insecurity of livestock, lack of adequate agricultural and livestock marketing, infrastructure, limited capacity of agriculture and livestock research centers, poor financial resources of farmers and livestock keepers, poor roads infrastructure, high number of IDPs. Shonia finance plays a vital role in the sustainability of any kind of business. Poor population of Bangladesh mostly faces the problem of financial and productive assets. Because of low income, no livelihood asset can be made $[1,5,6]$. Alam mentioned that insufficient income always creates problem to generate and continue income generation activity. Rahman et al stated that finance is a major obstacle for any kind of small scale business in rural areas.

\section{Methodology}

\section{Universe of the study}

The universe of the study was District and Tehsil Mansehra. Study area more specifically consisted of three villages i.e. Hilkot, Malookra and Balimang were randomly selected as a universe of the study for data collection.

\section{Sampling procedure and sample size}

A simple stratified random sampling methodology was used to select sample respondents for the purpose of data collection. A total sample of 210 respondents was selected for the total population size of 460 according to the method devised by Sekaran. The formula of proportion allocation sample size was applied to select sample size from each village as given below:

$$
\begin{aligned}
& n i=\frac{n}{N i} \times N i \\
& \mathrm{n}=\text { sample size of total population } \\
& \mathrm{ni}=\text { sample size of each population } \\
& \mathrm{Ni}=\text { no of the respondent in each department } \\
& \mathrm{N}=\text { total number of respondents. }
\end{aligned}
$$

\section{Data collection}

A well-established closed ended interview schedule was devised that encompass all the objectives and parameters of the study that helped in collecting of data from the respondents to understand their attitudes and obtaining desired data. It helped in analyzing collected data in statistical form. And the anonymity of participants was kept secret [7-9].

\section{Data processing and analysis}

The entering of data and its analysis was done through SPSS 20 version (Statistical Package for Social Sciences). In first phase of analysis, uni-variate analysis will be displayed for frequency and percentage distribution, while the second phase, Bi-variate analysis will be displayed for the association of independent variables and dependent variable.

Chi-square test: Chi-Square test statistics will be applied as a statistical tool to ascertain the relationship. To find the value of chisquare test, the formula will be as under:

$$
\chi^{2}=\sum_{i=1}^{r} \sum_{j=1}^{c} \frac{\left(O_{i j}-e_{i j}\right)^{2}}{e_{i j}}
$$

Where,

$$
\begin{aligned}
& \chi^{2}=\text { Chi Square } \\
& \mathrm{O}_{\mathrm{ij}}=\text { Observed frequencies in } \mathrm{i}^{\text {th }} \text { row and } \mathrm{j}^{\text {th }} \text { column } \\
& \mathrm{e}_{\mathrm{ij}}=\text { Expected frequencies regarding } \mathrm{i}^{\text {th }} \text { row and } \mathrm{j}^{\text {th }} \text { column } \\
& \mathrm{r}=\text { Number of rows } \\
& \mathrm{c}=\text { Number of columns } \\
& \mathrm{Df}=(\mathrm{r}-1)(\mathrm{c}-1) .
\end{aligned}
$$

\section{Results and Discussions}

\section{Rural livelihoods}

To measure the significance of rural livelihood, few statements regarding rural livelihood were asked from the respondents given in Table 1 , which shows that that majority $85.7 \%$ of respondents were agreed about the statement that agriculture is the main source of livelihood of the people in rural areas, moreover $12.9 \%$ of the whole sample size were disagreed with statement and $1.4 \%$ did not favor yes or no. Indira Nair stated the idea that agriculture is the major way of livelihood of rural population. For income and industrial production, agriculture output is of prime value, the same idea mentioned in a paper "Rural livelihoods, importance and definitions Unit 01 . Similarly, a majority $88.1 \%$ of respondents favored the statement that rural livelihoods are not static they adopt change, moreover $11.9 \%$ of respondents did not favored the statement. The idea is mentioned in Unit 01 of rural livelihoods, importance and definition. In the same way, big section 94.8\% respondents clicked "Yes" to show their positive attitude about the statement that sustainable livelihoods enhance female participation in livelihood activities, while $11.9 \%$ sample respondents clicked "No" and $1.4 \%$ came under section "Don't know. The idea confirmed by Doctor Rerum and Mündlichen Prüfung [10,11].

Nevertheless, a huge portion $90.5 \%$ of respondents showed positive attitude regarding the idea that livelihood satisfies the basic needs of family members, moreover $8.1 \%$ respondents negated the idea and 1.4 remained uncertain. The same idea stated by the UNDP, ISDR and IRP in "Guidance notes on recovery livelihoods, page 07. In response of a statement that rural livelihoods sustainability maintains the means of living of people, a majority $84.3 \%$ respondent accepted, moreover $11.4 \%$ negated and $4.3 \%$ of sample respondents did not know about the statement. Similarly, majority $90.5 \%$ of sample respondents were agreed with statement that rural employment is also a part of rural livelihoods, moreover, 9.5\% did not agreed about the statement. WaqasQayyum mentioned in "The Pakistan development review, part ii" that rural employment is a major way of making sustainable livelihood but absence of employment effect of household economy [12].

Furthermore, a heavy segment $85.7 \%$ respondent replied "Yes" 
to support the statement that skills trainings contributes in rural livelihoods, moreover 9.5\% respondents replied with "No" and $4.8 \%$ of respondents did not reply. Ali Shah and Shahbaz have presented the same idea that capacity building and skill development training on male side also contributed good results which enhances and reconstructed their livelihood as restarting business and earning income. In the same track, majority $80.5 \%$ of respondents thought that rural livelihoods also contain small scale businesses, moreover $10.0 \%$ did not think the statement was true and 9.5\% were unaware of the statement. Perret et al. stated the same idea in a study "Poverty and livelihoods in rural South Africa" [2]. Similarly, the great portion $87.1 \%$ respondents were in view that NGOs interventions in rural livelihood lead to sustainable rural livelihood, moreover $8.1 \%$ respondents showed their view against the statement and $4.8 \%$ did not share any view.

Additionally, the whole sample population agreed that rural livelihoods are affected by socioeconomic constrains and calamities. The idea strongly confirmed by Khatun and Roy [3]. Further a very proportion $93.8 \%$ pointed that sustainable livelihood provides livelihood opportunities to next generation, moreover $1.8 \%$ opposed the idea and $1.4 \%$ did not response [13]. Robert Chambers and Gorden Conway have support the same idea in a paper "sustainable rural livelihood" [6]. Likewise, majority $82.4 \%$ respondents supported the view that sustainable livelihood approach improves the condition of poor, moreover $9.0 \%$ did not agree with majority and $8.6 \%$ did not share any idea. The idea confirmed Sheial Meikem Tamsin Ramasut and Julian Walker and UNDP.

Furthermore, a big portion $83.3 \%$ agreed with statement that rural livelihoods also contain nonagricultural activities in rural areas, moreover 11.4 were not agrees and 5.2\% did not answer. Perret et al. also stated that rural people are engaged in agriculture activities as farmers and also carry out non-farm activities, also in rural area people are involved in production includes farming, local craft, and small level business, and trading is also an important source of rural livelihood [2]. Similarly the big part $82.9 \%$ respondents were of the opinion that sustainable livelihood does not adversely affect environment, moreover $11.9 \%$ did not of the same opinion and $6.2 \%$ did not share any opinion. The same idea also mentioned by Robert Chamber and Gorden Conway in a paper "sustainable rural livelihood" (Table 1) [6].

\section{Association between socioeconomic constraints and rural livelihoods}

Sustainable rural livelihood depends on socioeconomic condition of households. Adversely effect on rural livelihood because of socioeconomic constrains is a universal phenomenon. Weakness of rural livelihoods and socioeconomic factors are related as a number of studies have proved. The complex association between rural livelihoods and socioeconomic condition is an observable fact. A few statements were developed to review that association. Respondents and their attitudes regarding the socioeconomic constrains are given in Table 2. Finance is the core problem for all categories of entrepreneurs in rural areas was found highly significant $(\mathrm{p}=0.000)$ with rural livelihoods. Rahman et al. confirmed that finance is the core problem for expansion of activities in all categories of entrepreneurs in rural areas. Sheheli has stated the finance as core problem of rural poor. Moreover, poor health issues block sustainability of rural livelihood was also found highly significant $(p=0.000)$. These findings are in line with the findings of Zimbabve, ZimVac that inadequate health facilities affect rural livelihoods [14].

In the same way, the statement that prevalence of diseases in livestock and crops contribute income decline in rural areas was found significant $(\mathrm{p}=0.003)$ with rural livelihoods. WFP and FAO mentioned in their study that high level of crop pest infestation and prevalence of livestock diseases are obstacles of rural livelihood [4,5].

Moreover, the idea that marketing problem is a major obstacle in rural economy production was also found significant $(\mathrm{p}=0.003)$ with rural livelihoods. The result supported by earlier study Zimbabve Vulnerability Assessment Committee. Furthermore, the idea that land shortage affects directly rural economy was found significant $(\mathrm{p}=0.005)$ with rural livelihoods. These results are similar with the findings of Jennifar.

Furthermore, a significant relatiion $(\mathrm{p}=0.007)$ was found between rural livelihoods affect adversely by any kind of shock and rural livelihoods. These findings are similar with the study of FAO [3,5]. Similarly a significant relation was found $(p=0.014)$ between Illiteracy affects negatively sustainability of rural livelihood and rural livelihoods. The idea conformed Khatun and Roy in a study 'Rural Livelihood diversification, determination and constraints [3].

In the same way, significant relation $(\mathrm{p}=0.021)$ was found between the statement that conflict leads decline in rural livelihoods and rural livelihoods. World Food Program, WFP, and Food and Agriculture Organization, FAO, also stated that conflicts over different resources make livelihood unstable $[4,5]$. However, a non-significant relation ( $\mathrm{p}=0.354$ ) was found between the idea that unstable product prices

\begin{tabular}{|c|c|c|c|c|}
\hline Statement & Yes & No & Don't Know & Total \\
\hline Agriculture is the main source of livelihood of the people in rural areas & $180(85.7 \%)$ & $27(12.9 \%)$ & $3(1.4 \%)$ & $210(100 \%)$ \\
\hline Rural livelihoods are not static they adopt changes & $185(88.1 \%)$ & $25(11.9)$ & $0(0.00 \%)$ & $210(100 \%)$ \\
\hline Sustainable livelihood enhances female participation in livelihood activities & $199(94.8 \%)$ & $8(3.8 \%)$ & $3(1.4 \%)$ & $210(100 \%)$ \\
\hline Livelihood satisfies the basic needs of family members & $190(90.5 \%)$ & $17(8.1 \%)$ & $3(1.4 \%)$ & $210(100 \%)$ \\
\hline Rural livelihoods sustainability maintains the means of living of people & $177(84.3 \%)$ & $24(11.4 \%)$ & $9(4.3 \%)$ & $210(100 \%)$ \\
\hline Rural employment in also a part of rural livelihood & $190(90.5 \%)$ & $20(9.5 \%)$ & $0(0.00 \%)$ & $210(100 \%)$ \\
\hline Skills trainings contribute in rural livelihood & $180(85.7 \%)$ & $20(9.5 \%)$ & $10(4.8 \%)$ & $210(100 \%)$ \\
\hline Rural livelihoods also contain small scale businesses & $169(80.5 \%)$ & $21(10.0 \%)$ & $20(9.5 \%)$ & $210(100 \%)$ \\
\hline NGOs intervention in rural livelihood leads to sustainable rural livelihood & $183(87.1 \%)$ & $17(8.1 \%)$ & $10(4.8 \%)$ & $210(100 \%)$ \\
\hline Rural livelihoods are affected by socioeconomic constrains and calamities & $210(100 \%)$ & $0(0.00 \%)$ & $0(0.00 \%)$ & $210(100 \%)$ \\
\hline Sustainable livelihood provides livelihood opportunities to next generation & $197(93.8)$ & $10(4.8 \%)$ & $3(1.4 \%)$ & $210(100 \%)$ \\
\hline Sustainable livelihood approach improves the condition of poor & $173(82.4 \%)$ & $19(9.0 \%)$ & $18(8.6 \%)$ & $210(100 \%)$ \\
\hline Rural livelihoods also contain nonagricultural activities in rural areas & $175(83.3 \%)$ & $24(11.4 \%)$ & $11(5.2 \%)$ & $210(100 \%)$ \\
\hline Sustainable livelihood does not adversely affect environment & $174(82.9 \%)$ & $23(11.0 \%)$ & $13(6.2 \%)$ & $210(100 \%)$ \\
\hline
\end{tabular}

Value in the table present frequency while values in the parenthesis represent percentages proportion of the respondents

Table 1: Frequency distribution and proportion of rural livelihoods. 
Citation: Sajid A, Ayatullah, Khan NA, Iqbal S, Abbas S, et al. (2018) Socio-Economic Constraints Affecting Sustainable Rural Livelihood. Arts Social Sci J 9: 324. doi: 10.4172/2151-6200.1000324

Page 4 of 5

\begin{tabular}{|c|c|c|c|c|c|c|}
\hline \multirow[t]{2}{*}{ Statement } & \multirow[t]{2}{*}{ Perception } & \multicolumn{3}{|c|}{ Rural livelihoods } & \multirow[t]{2}{*}{ Total } & \multirow[t]{2}{*}{ Chi-Square (P-Value) } \\
\hline & & Yes & No & Don't Know & & \\
\hline \multirow{3}{*}{$\begin{array}{l}\text { Finance is the core problem } \\
\text { for all categories of } \\
\text { entrepreneurs in rural areas }\end{array}$} & Yes & $167(83.6)$ & $26(12.9)$ & $7(3.5)$ & $201(100.0)$ & \multirow{3}{*}{$\chi^{2}=18.288(p=0.000)$} \\
\hline & No & $4(44.4)$ & $2(22.2)$ & $3(33.3)$ & $9(100.0)$ & \\
\hline & Don't know & 0 & 0 & 0 & 0 & \\
\hline \multirow{3}{*}{$\begin{array}{l}\text { Conflict leads decline in rural } \\
\text { livelihood }\end{array}$} & Yes & $167(83.1)$ & $26(12.9)$ & $8(4.0)$ & $201(100.0)$ & \multirow[t]{3}{*}{$\chi^{2}=11.539(p=0.021)$} \\
\hline & No & $4(57.1)$ & $1(14.3)$ & $2(28.6)$ & $7(100.0)$ & \\
\hline & Don't know & $1(50.0)$ & $1(50.0)$ & $0(0.0)$ & $2(100.0)$ & \\
\hline \multirow{3}{*}{$\begin{array}{l}\text { Unstable product prices } \\
\text { results poor income }\end{array}$} & Yes & $91(83.5)$ & $14(12.8)$ & $4(3.7)$ & $109(100.0)$ & \multirow[t]{3}{*}{$\chi^{2}=4.403(p=0.354)$} \\
\hline & No & $47(87.0)$ & $5(9.3)$ & $2(3.7)$ & $54(100.0)$ & \\
\hline & Don't know & $34(72.3)$ & $9(19.1)$ & $4(8.5)$ & $47(100.0)$ & \\
\hline \multirow{3}{*}{$\begin{array}{l}\text { Prevalence of heavy } \\
\text { livestock and crop diseases } \\
\text { contribute income decline in } \\
\text { rural areas }\end{array}$} & Yes & $153(84.1)$ & $24(13.2)$ & $5(2.7)$ & $182(100.0)$ & \multirow[t]{3}{*}{$\chi^{2}=16.072(p=0.003)$} \\
\hline & No & $14(77.8)$ & $1(5.6)$ & $3(16.7)$ & $18(100.0)$ & \\
\hline & Don't know & $5(50.0)$ & $3(30.0)$ & $2(20.0)$ & $10(100.0)$ & \\
\hline \multirow{3}{*}{$\begin{array}{l}\text { Difficulty in obtaining raw } \\
\text { material create hindrance for } \\
\text { rural livelihood }\end{array}$} & Yes & $129(87.2)$ & $19(12.2)$ & $8(5.1)$ & $156(100.0)$ & \multirow[t]{3}{*}{$\chi^{2}=1.116(0.892)$} \\
\hline & No & $42(79.2)$ & $9(17.0)$ & $2(3.8)$ & $53(100.0)$ & \\
\hline & Don't know & $1(100.0)$ & $0(0.00)$ & $0(0.00)$ & $1(100.0)$ & \\
\hline \multirow{3}{*}{$\begin{array}{l}\text { Marketing problem is a major } \\
\text { obstacle in rural economy } \\
\text { production }\end{array}$} & Yes & $166(83.0)$ & $26(13.0)$ & $8(4.0)$ & $200(100.0)$ & \multirow[t]{3}{*}{$\chi^{2}=16.267(p=0.003)$} \\
\hline & No & $4(66.7)$ & $0(0.00)$ & $2(33.3)$ & $6(100)$ & \\
\hline & Don't know & $2(50.0)$ & $2(50.0)$ & $0(0.00)$ & $4(100.0)$ & \\
\hline \multirow{3}{*}{$\begin{array}{l}\text { Poor infrastructure always } \\
\text { negatively affects rural } \\
\text { economy }\end{array}$} & Yes & $153(83.2)$ & $21(11.4)$ & $10(5.4)$ & $184(100.0)$ & \multirow[t]{3}{*}{$\chi^{2}=5.806(p=0.055)$} \\
\hline & No & $19(73.1)$ & $7(26.9)$ & $0(0.00)$ & $26(100)$ & \\
\hline & Don't know & $0(0.00)$ & $0(0.00)$ & $0(0.00)$ & $0(0.00)$ & \\
\hline \multirow{3}{*}{$\begin{array}{l}\text { Land shortage affects } \\
\text { directly rural economy }\end{array}$} & Yes & $165(82.9)$ & $26(13.1)$ & $8(4.0)$ & $199(100.0)$ & \multirow[t]{3}{*}{$\chi^{2}=14.879(p=0.005)$} \\
\hline & No & $2(40.0)$ & $1(20.0)$ & $2(40.0)$ & $5(100.0)$ & \\
\hline & Don't know & $5(83.3)$ & $1(16.7)$ & $0(1.00)$ & $6(100.0)$ & \\
\hline \multirow{3}{*}{$\begin{array}{l}\text { Power shortage always } \\
\text { jeopardy rural livelihood }\end{array}$} & Yes & $139(81.8)$ & $25(14.7)$ & $6(3.5)$ & $170(100.0)$ & \multirow[t]{3}{*}{$\chi^{2}=5.067(p=0.280)$} \\
\hline & No & $28(82.4)$ & $3(8.8)$ & $3(8.8)$ & $34(100.0)$ & \\
\hline & Don't know & $5(83.3)$ & $0(0.00)$ & $1(16.7)$ & $6(100.0)$ & \\
\hline \multirow{3}{*}{$\begin{array}{l}\text { Illiteracy affects negatively } \\
\text { sustainability of rural } \\
\text { livelihood }\end{array}$} & Yes & $167(83.1)$ & $24(11.9)$ & $10(5.0)$ & $201(100.0)$ & $\chi^{2}=12.500(p=0.014)$ \\
\hline & No & $3(42.9)$ & $4(57.1)$ & $0(0.00)$ & $7(100.0)$ & \\
\hline & Don't know & $2(100.0)$ & $0(0.00)$ & $0(0.00)$ & $2(100.0)$ & \\
\hline Poor health issues block & Yes & $157(84.0)$ & $26(13.9)$ & $4(2.1)$ & 187)100.0) & $\chi^{2}=28.622(p=0.000)$ \\
\hline sustainability of rural & No & $10(71.4)$ & $0(0.000$ & $4(28.6)$ & $14(100.0)$ & \\
\hline & Don't know & $5(55.6)$ & $2(22.2)$ & $2(22.2)$ & $9(100.0)$ & \\
\hline Heavy interest on loan & Yes & $159(81.5)$ & $26(13.3)$ & $10(5.1)$ & $195(100.0)$ & $\chi^{2}=0.824(p=0.935)$ \\
\hline discourages rural livelihood & No & $6(85.7)$ & $1(14.3)$ & $0(0.00)$ & $7(100.0)$ & \\
\hline & Don't Know & $7(87.5)$ & $1(12.5)$ & $0(0.00)$ & $8(100.0)$ & \\
\hline Rural livelihood affected & Yes & $167(83.1)$ & $26(12.9)$ & $8(4.0)$ & $201(100.0)$ & $\chi^{2}=14.069(p=0.007)$ \\
\hline adversely by any kind of & No & $5(62.5)$ & $1(12.5)$ & $2(25.0)$ & $8(100.0)$ & \\
\hline & Don't Know & $0(0.00)$ & $1(100.0)$ & $0(0.00)$ & $1(100.0)$ & \\
\hline Low income cause to crush & Yes & $165(82.5)$ & $27(13.5)$ & $8(4.0)$ & $200(100.0)$ & $\chi^{2}=5.389(p=0.068)$ \\
\hline $\begin{array}{l}\text { IIvelihood sustainability in } \\
\text { rural area }\end{array}$ & No & $7(70.0)$ & $1(10.0)$ & $2(20.0)$ & $10(100.0)$ & \\
\hline & Don't Know & $0(0.00)$ & $0(0.00)$ & $0(0.00)$ & $0(0.00)$ & \\
\hline
\end{tabular}

Number in table represent frequencies and number in parenthesis represent percentage proportion of respondents and in the last columns number in the parenthesis represent P-value.

Table 2: Association between socioeconomic constrains and sustainable rural livelihood.

results poor income and rural livelihoods. WFP and FAO stated the unstable product price is one of issues in rural livelihoods [4,5]. Similarly, a non-significant relation $(\mathrm{p}=0.892)$ was found between difficulty in obtaining raw material create hindrance for rural livelihood and rural livelihoods. The findings confirmed by Marof Redzuan and Fariborz Aref in a study conducted in underdeveloped region of Malaysia.

In addition, non-significant relation $(\mathrm{p}=0.055)$ was found between the poor infrastructure always negatively affects rural economy and rural livelihoods. The result is similar with the findings of Okechukwu Agwu that poor infrastructure always negatively affects rural livelihoods. Similarly, a non-significant relationship $(\mathrm{p}=0.280)$ was found between power shortage always jeopardy rural livelihood and rural livelihoods.
In the same row, non-significant relationship $(\mathrm{p}=0.935)$ was found between the idea that heavy interest on loan discourages rural livelihood and rural livelihoods. Likewise, result illustrate that a nonsignificant relation $(\mathrm{p}=0.068)$ was found between low income cause to crush livelihood sustainability in rural area and rural livelihoods. The statement confirmed WFPU, FAO, Marof Redzuan and FariborzAref low income is one of major issues of rural livelihoods [4,5].

\section{Conclusions}

This study focused on the investigation into the factors behind rural livelihood. It was concluded that rural livelihood was a general phenomenon throughout the world. Rural livelihood mostly consisted 
Citation: Sajid A, Ayatullah, Khan NA, Iqbal S, Abbas S, et al. (2018) Socio-Economic Constraints Affecting Sustainable Rural Livelihood. Arts Social Sci J 9: 324. doi: 10.4172/2151-6200.1000324

Page 5 of 5

upon agriculture and some other activities. Pakistan is one of third world countries consisted upon a major portion of rural areas. Lack of finance, conflicts, livestock and crops diseases, land shortage, health issues, illiteracy, marketing problem and any kind of shock are contributing factors making rural livelihood unstable.

\section{References}

1. Chambers R, Conway G (1992) Sustainable rural livelihoods: practical concepts for the 21st century. Institute of Development Studies (UK)

2. Perret S, Anseeuw W, Mathebula F (2005) Poverty and livelihoods in rura South Africa Investigating diversity and dynamics of livelihoods Case studies in Limpopo Pretoria. South Africa University of Pretoria Kellogg's Foundation.

3. Khatun D, Roy BC (2012) Rural livelihood diversification in West Bengal: determinants and constraints. Agricultural Economics Research Review 25 : $115-124$

4. WFPU (2005) Emergency Food Security and Nutrition Assessment in Darfur Sudan. Provisional Report Khartoum \& Khartoum World Food Programme.

5. World Food Programme WFP, Food and Agriculture Organization FAO (2012) Situation Analysis Agriculture Livestock and Rural livelihoods in the greater Darfur region: Sudan.

6. Bennett J (1998) Development Alternatives: NGO Government Partnership in Pakistan 41: 54-57
7. Ahmad S (2004) Gender Issues in Agriculture and Rural Livelihoods MS Swaminathan Research Foundation Uttara Devi Resource. Centre for Gender and Development India.

8. Boudreau T (1998) The food economy approach: a framework for understanding rural livelihoods London: Overseas Development Institute.

9. Hassan A, Forhad A (2013) The role of NGOS in the sustainable development in Bangladesh. Present Environment \& Sustainable Development Vol-7.

10. Krantz $L$ (2001) The sustainable livelihood approach to poverty reduction SIDA Division for Policy and Socio-Economic Analysis.

11. Mavhura E, Manatsa D, Mushore T (2015) Adaptation to drought in arid and semi-arid environments: Case of the Zambezi Valley ZimbabweJàmbá: Journal of Disaster Risk Studies Vol-7 pp: 7.

12. Oni OA, Fashogbon AE (2013) Food poverty and livelihoods issues in rura Nigeria. African Journal of Agricultural and Resource Economics 8: 108-135.

13. Quan J (2002) Better livelihoods for poor people: the role of land policy Discussion draft Department for International Development (DFID) London.

14. Sheheli S (2012) Improving livelihood of rural women through income generating activities in Bangladesh. (Doctoral dissertation Humboldt-Universitätzu Berlin Landwirtschaftlich-GärtnerischeFakultät) 